\title{
Menumbuhkan Kesadaran Hidup Ekologis melalui Komunikasi Lingkungan di Eco Learning Camp
}

\author{
${ }^{1}$ Santi Susanti, ${ }^{2}$ Tine Silvana Rachmawati \\ ${ }^{1,2}$ )Fakultas Ilmu Komunikasi, Universitas Padjadjaran, Jl. Raya Bandung Sumedang Km 21, Jatinangor \\ E-mail: 'santi.susanti@unpad.ac.id, ${ }^{2}$ tine.silvana@unpad.ac.id
}

\begin{abstract}
Abstrak: Penelitian ini bertujuan untuk mengungkapkan bentuk-bentuk komunikasi lingkungan yang diterapkan di Eco Learning Camp atau Eco Camp, Bandung dalam menumbuhkan kesadaran hidup ekologis. Eco Camp adalah suatu lembaga nirlaba yang memiliki tujuan membangun kesadaran masyarakat untuk menjaga kelestarian alam dan hidup harmonis dengan alam sebagai sesama ciptaan Tuhan. Metode yang digunakan adalah kualitatif deskriptif, berupa pengamatan akan situasi yang di alami serta wawancara dengan pengelola Eco Camp. Penelitian ini menghasilkan temuan, Eco Camp memiliki tujuh kesadaran baru hidup ekologis yang diterapkan dalam kehidupan sehari-hari di lingkungan Eco Camp, dimulai dari lingkungan internal pengelolanya sejak bangun tidur hingga menjelang tidur. Muara dari aktivitas yang dilakukan adalah munculnya kesadaran pentingnya menjaga hubungan baik dengan alam, agar alam memberikan timbal balik yang baik pula bagi manusia. Kesimpulan dari penelitian ini adalah komunikasi lingkungan yang menarik dan terpolakan dalam suatu lembaga yang peduli akan lingkungan hidup dapat memberikan kontribusi bagi munculnya kesadaran untuk menjaga hubungan baik antara manusia dengan lingkungan alam sekitar.
\end{abstract}

Kata kunci: hidup ekologis, harmonis dengan alam, komunikasi lingkungan, kearifan lokal.

\begin{abstract}
This study aims to reveal the forms of environmental communication applied at Eco Learning Camp or Eco Camp Bandung in fostering awareness of ecological life. Eco Camp is a non-profit institution that aimed to build public awareness to preserve nature and live in harmony with nature as a fellow creation of God. The method used is descriptive qualitative, in the form of observations of experienced situation and interviews with Eco Camp managers. This research resulted in findings ; Eco Camp has seven new awareness of ecological life that is applied in daily life in the Eco Camp environment, starting from the internal environment of its management, since waking up until before going to bed. The activities is expected to emerge awareness of the importance of maintaining good relations with nature, so that nature provides good reciprocity for humans. The conclusion of this study is that attractive and patterned enviromental communication in an institution that cares about the environment can contribute to the emergence of awareness to maintain good relations between humans and natural environment.
\end{abstract}

Keywords: ecological life, harmony with nature, environmental communication, local wisdom 


\section{PENDAHULUAN}

Kualitas lingkungan hidup saat ini sudah mulai berkurang sebagai akibat dari perilaku manusia dalam memenuhi kebutuhan hidupnya yang kurang memerhatikan dampaknya bagi lingkungan hidup. Pengelolaan sampah yang tidak ramah lingkungan, limbah yang tidak dikelola dengan baik, alih fungsi lahan, perumahan dan sebagainya, turut berkontribusi pada rusaknya lingkungan alam. Perubahan iklim dan pemanasan global merupakan efek yang paling dirasakan saat ini. Cuaca menjadi tidak menentu dan suhu bumi pun bertambah panas. Gunung es sudah berkurang karena banyak yang mencair. Masyarakat di berbagai negara merasakan beberapa tahun belakangan ini merasakan suhu udara di bumi bertambah panas dan banyak wilayah yang kekeringan akibat panasnya cuaca ini.

Dampak tersebut dapat mengancam kelangsungan perikehidupan manusia dan makhluk hidup lainnya sehingga perlu dilakukan perlindungan dan pengelolaan lingkungan yang baik agar kualitas lingkungan hidup tidak menurun secara drastis.

Kesadaran akan pentingnya menjaga kelestarian lingkungan hidup penting dimiliki oleh setiap individu, karena kita tidak bisa mengandalkan satu pihak untuk menjaga lingkungan tetap lestari, karena upaya pelestarian akan lebih tepat sasaran dan tepat guna, jika semua pemangku kepentingan ikut serta dalam upaya tersebut.

Gerakan lingkungan hidup tumbuh bukan karena hobi, trend, minat atau terpaksa, melainkan karena semakin meningkatnya kesadaran akan krisis lingkungan hidup Gerakan lingkungan hidup adalah gerakan terbesar di dunia dengan lebih dari dua juta lembaga yang aktif dalam lingkungan hidup

Ada tiga bentuk gerakan lingkungan hidup, yaitu advokasi, aksi nyata dan edukasi. Yayasan Lingkungan Hidup yang didirikan oleh kumpulan individu yang peduli lingkungan hidup, memilih bentuk edukasi untuk menanamkan pentingnya bersahabat dengan alam dan menjaga lingkungan hidup dengan baik melalui pendidikan.

Eco Learning Camp atau Eco Camp merupakan suatu lembaga nirlaba yang fokus pada pendidikan lingkungan hidup bagi anak-anak hingga orang dewasa berbasiskan alam, budaya dan ilmu pengetahuan. Eco Camp didirikan pada tahun 2012, dengan lokasi di Taman Hutan Raya Ir. H. Djuanda, Dago, Bandung. Eco Camp membuat beragam program yang bertujuan menanamkan kesadaran kepada individu maupun kelompok peserta pendidikan Eco Camp untuk menjaga lingkungan dan menjalani hidup dengan pola ekologis.

Mengacu pada pemaparan sebelumnya, maka tujuan dari penelitian ini adalah menggambarkan bagaimana Eco Camp menanamkan rasa kepedulian terhadap lingkungan hidup melalui komunikasi lingkungan dalam bentuk pendidikan ekologi yang dirancangnya kepada peserta pendidikan dan pengelola Eco Camp.

Dalam tulisan ini terdapat konsepkonsep pokok yang menjadi bagian utama dalam pembahasan permasalahan penelitian. Konsep-konsep tersebut adalah komunikasi lingkungan, kearifan lokal, dan hidup ekologis.

Dalam tulisannya di Kompas. com, Angga Ariestya (2017), praktisi komunikasi lingkungan di International for Research in Agroforestry (ICRAF), menjelaskan bahwa komunikasi lingkungan merupakan bidang studi dalam keilmuan komunikasi yang mengkaji keterkaitan komunikasi dengan hubungan manusia dan alam (humannature relation). Studi ini pertama muncul di Amerika tahun 1980-an dari tradisi teori retorika. 
Menurut Angga, komunikasi lingkungan memiliki dua fungsi utama, yakni fungsi strategis dan fungsi teknis. Fungsi strategis komunikasi lingkungan adalah kampanye dan meningkatkan kesadaran khalayak untuk peduli terhadap lingkungan. Tujuannya mengajarkan, mengajak, serta mendorong pemerintah, swasta, dan masyarakat berperan serta dalam mengatasi permasalahan lingkungan. Caranya dengan menggiatkan kampanye-kampanye sosial terkait isuisu lingkungan, melakukan penyuluhan, dan meningkatkan hubungan pemerintah dalam melakukan advokasi untuk mendorong suatu kebijakan yang pro terhadap isu lingkungan.

Fungsi teknik dilakukan dalam rangka mengumpulkan, memublikasikan, dan menyebarkan informasi terkait isuisu lingkungan. Tujuannya memberikan informasi kepada khalayak tentang permasalahan-permasalahan lingkungan. Bentuknya dapat berupa publikasi, liputan media, tulisan di website, media sosial, dan sebagainya.

Komunikasi lingkungan dibangun dalam budayanya. Flor, dalam Rahmat (2018), mengemukakan, komunikasi lingkungan dibangun dalam budaya, khususnya dalam budaya tradisional. Konsekuensinya, komunikasi lingkungan seharusnya selalu mengandung dimensi budaya yang melingkupinya. Dalam interaksinya denganalamuntukmemenuhi kebutuhannya, manusia melakukan adaptasi dengan lingkungannya. Adaptasi tersebut menghasilkan suatu pengetahuan tradisional yang dikenal dengan kearifan lokal, yaitu nilai-nilai luhur yang berlaku dalam tata kehidupan masyarakat untuk antara lain melindungi dan mengelola lingkungan hidup secara lestari. Dalam interaksinya dengan alam, berdasarkan kearifan lokal, manusia memanfaatkan potensi alam sesuai dengan keperluannya dan tidak berlebihan.(Indrawardana, 2012)
Quaritch Wales (dalam Budiwiyanto, 2006) menyebut kearifan lokal sebagai "local genius" yang berarti sejumlah ciri kebudayaan yang dimiliki bersama oleh suatu masyarakat sebagai suatu akibat pengalamannya di masa lalu. Suhartini (2009) mengartikan kearifan lokal sebagai suatu bentuk kearifan lingkungan yang ada dalam kehidupan bermasyarakat di suatu tempat atau daerah yang merujuk pada lokalitas dan komunitas tertentu. Sedangkan Fajarini (2014) mengartikan kearifan lokal sebagai pandangan hidup dan ilmu pengetahuan serta berbagai strategi kehidupan yang berwujud aktivitas yang dilakukan masyarakat lokal dalam menjawab berbagai masalah pemenuhan kebutuhan mereka.

Bagi Negara (2011), kearifan lokal bukan hanya menyangkut pengetahuan atau pemahaman masyarakat adat/ lokal tentang manusia dan bagaimana relasi yang baik di antara manusia, juga menyangkut pengetahuan, pemahaman, dan adat kebiasaan tentang manusia, alam, dan bagaimana relasi di antara semua, dimana seluruh pengetahuan itu dihayati, dipraktikkan, diajarkan, dan diwariskan dari satu generasi ke generasi.

Terkait dengan pelestarian lingkungan hidup, Undang-Undang Nomor 32 Tahun 2009 tentang Perlindungan dan Pengelolaan Lingkungan pada Pasal 1 ayat 30, menyatakan "kearifan lokal adalah nilai-nilai luhur yang berlaku dalam tata kehidupan masyarakat untuk antara lain melindungi dan mengelola lingkungan hidup secara lestari."

Upaya menjaga keseimbangan dengan lingkungannya masyarakat memiliki norma-norma, nilai-nilai atau aturan-aturan yang telah berlaku turun temurun yang merupakan kearifan lokal setempat. Beberapa contoh praktik budaya dan kearifan lokal di Jawa Barat menurut Suhartini dalam Maridi (2015) 
antara lain sebagai berikut:

Baduy Dalam; Segala tingkah laku masyarakat Baduy harus berpedoman kepada buyut yang telah ditentukan dalam bentuk pikukuh karuhun (aturan leluhur). Seseorang tidak berhak dan tidak berkuasa untuk melanggar dan mengubah tatanan kehidupan yang telah ada dan sudah berlaku turun temurun. Beberapa pikukuh yang harus ditaati oleh masyarakat Baduy atau masyarakat luar yang berkunjung ke Baduy antara lain: (1) dilarang masuk hutan larangan (leuweung kolot) untuk menebang pohon, membuka ladang, atau mengambil hasil hutan lainnya; (2) dilarang menebang sembarang jenis tanaman, misalnya buah-buahan dan jenis jenis tertentu; (3) dilarang menggunakan teknologi kimia seperti pupuk dan pestisida untuk meracuni ikan; serta (4) berladang harus sesuai dengan ketentuan adat.

Budaya pamali di Kampung Kuta Ciamis; Aulia dan Dharmawan (2010) menjelaskan, budaya pamali merupakan suatu aturan atau norma yang mengikat kehidupan masyarakat Kampung Kuta Ciamis. Penerapan budaya pamali ini dilakukan dalam pemeliharaan sumber daya air yang digunakan untuk memenuhi kebutuhan sehari-hari dan untuk ritual adat. Air yang digunakan untuk kebutuhan sehari-hari diperoleh dari empat mata air yaitu Cibungur, Ciasihan, Cinangka, dan Cipanyipuhan. Masyarakat dilarang untuk menggali sumur sendiri agar kondisi air bawah tanah selalu baik. Sumber daya air yang ada di dalam hutan Keramat tidak dimanfaatkan untuk keperluan seharihari karena terdapat larangan untuk memanfaatkan sumberdaya yang ada di Hutan Keramat. Sumberdaya air di Hutan Keramat hanya digunakan untuk upacara adat ritual nyipuh. Adanya budaya pamali dalam pengelolaan Hutan Keramat terbukti menjaga kelestarian ekosistem di dalamnya sehingga sumberdaya air juga terjaga dengan baik.
Hidup ekologis dimaknai oleh pengelola Eco Camp sebagai hidup sederhana, yaitu lebih hemat dan lebih peduli terhadap sumber energi, seperti air dan makanan. Makanan sederhana bukan berarti mengurangi lauk pauk dan makan seirit mungkin, melainkan berusaha mengurangi makan daging, karena industri daging merupakan penyumbang terbesar pemanasan global saat ini. Menurut Ferry, tujuan akhir dari hidup ekologis adalah membentuk karakter yang sadar akan lingkungannya, mau hidup hemat, supaya bisa peduli dan berbagi dengan orang lain.

"Kalau semua orang serakah, ya tambah rusak. Kalau semua orang menghambur-hamburkan air dan listrik. Ya tidak cukup lah persediaan. Jadi sederhana ini alasan sekaligus tujuan agar lingkungan tidak tambah rusak, tapi tetap terpelihara," kata Ferry (http:// news.unika.ac.id/2017/09/lewat-diskusipublik-kenalkan-cara-baru-hidupekologis/ diakses 10/11/2018).

\section{METODE}

Metode yang digunakan dalam penelitian ini adalah kualitatif deskriptif dengan pendekatan fenomenologi, untuk menggambarkan pendidikan yang dilakukan di Eco Camp dalam rangka menanamkan kepedulian terhadap lingkungan hidup berdasarka sudut pandang informan.

Data penelitian diperoleh melalui wawancara, observasi, serta kajian pustaka yang terkait dengan penelitian. Wawancara dilakukan kepada pengelola Eco Camp untuk mengetahui latar belakang serta tujuan pendirian Eco Camp melakukan aktivitas pendidikan lingkungan hidup, serta penerapan komunikasi lingkungan kepada para peserta pendidikan dan pengelola Eco Camp. Observasi dilakukan secara partisipatif untuk mengetahui dan merasakan suasana serta situasi ketika 
pendidikan di Eco Camp. Kajian pustaka dilakukan melalui tinjauan terhadap artikel atau tulisan serta foto dan video yang terkait dengan pendidikan lingkungan hidup di Eco Camp.

Subjek penelitian ini adalah Eco Camp sebagai penyelenggara pendidikan lingkungan hidup yang bertujuan membangun kesadaran menjaga dan merawat lingkungan alam untuk mewujudkan hidup yang lebih baik dan lebih bersahabat dengan lingkungan. Objek penelitian ini adalah aktivitas pendidikan lingkungan hidup yang dilakukan di Eco Camp.

\section{TEMUAN DAN PEMBAHASAN Sekilas Eco Learning Camp}

Eco Learning Camp merupakan pengembangan dari Spirit Camp yang didirikan pada tahun 2002 oleh Yayasan Sahabat Lingkungan hidup. Pendirian Yayasan berawal dari kepedulian terhadap anak-anak dan masa depan mereka. Awalnya, Spirit Camp berlokasi di daerah Ledeng, Bandung. Spirit Camp menyediakan sejumlah aktivitas dan fasilitas untuk anak-anak dan remaja, agar mereka dapat bermain di alam terbuka. Aktivitas Spirit Camp sempat berpindah ke Kota Baru Parahyangan sebelum akhirnya pada tahun 2012 berlokasi di Taman Hutan Raya Ir. H. Djuanda, Dago, Bandung. Berevolusi menjadi Eco Learning Camp atau Eco Camp di bawah Yayasan Sahabat Lingkungan Hidup, organisasi ini didirikan untuk mengembangkan aktivitas edukasi, konservasi, riset, dan pengembangan komunitas serta berbagai aktivitas kreatif lainnya yang berbasis lingkungan.

Eco Camp saat ini berlokasi di Jalan Dago Pakar Barat 3 Bandung, dekat Tahuara Djuanda, menempati lahan kurang lebih 5400 meter persegi. Di atas lahan tersebut, Eco Camp digunakan sebagai sarana untuk mengadakan berbagai pertemuan dan pelatihan dalam bidang pendidikan dan lingkungan hidup. Eco Camp juga di bangun dengan mengikuti kriteria Green Building Council Indonesia.

Dalam menjalankan aktivitasnya, Eco Camp memiliki visi untuk menghasilkan manusia berkualitas yang peduli merawat bumi dan berguru pada bumi. Konsep merawat bumi dan berguru pada bumi, yang dalam bahasa Sunda adalah mulasara bumi, guguru ka bumi merupakan suatukonsep yang berdasarkan pada kearifan lokal masyarakat Sunda untuk selalu dekat dengan alam, dan menjadikan alam sebagai bagian yang tidak terpisahkan dari hidup manusia Sunda. Dalam praktiknya, manusia hidup bukan untuk menaklukkan alam, tapi untuk beradaptasi dengan alam.

Dalam ecolearningcamp.org, dijelaskan, konsep merawat bumi versi eco camp difokuskan pada merawat tiga unsur alam, yakni air, tanah dan udara. Lebih lengkapnya adalah menghormati daur ulang air untuk masuk ke dalam tanah, mengembalikan keutuhan tanah, dan bersih dari polusi. Mengembalikan ketiganya berarti menyelamatkan kehidupan. Sementara itu, konsep berguru pada bumi dimaknai secara filosofis untuk berguru pada benda-benda alam yang berkaitan dengan bumi, yakni gunung, mata air, pohon dan bunga. Dari gunung kita belajar keteguhan, dari mata air kita belajar tumbuh, dari pohon kita belajar sabar berproses dan dari bunga, kita belajar keindahan.

Dengan misi antara lain membangun generasi muda yang memiliki kesadaran akan lingkungan hidup yang lebih baik dan meningkatkan kualitas hidup melalui edukasi, konservasi, penelitian, dan pemberdayaan masyarakat, Eco Camp mengajak sesama mencintai alam semesta hingga muncul keinginan untuk memelihara dan berguru kepada alam. Dalam mengelola Eco Camp, Yayasan Sahabat Lingkungan Hidup bekerja sama 


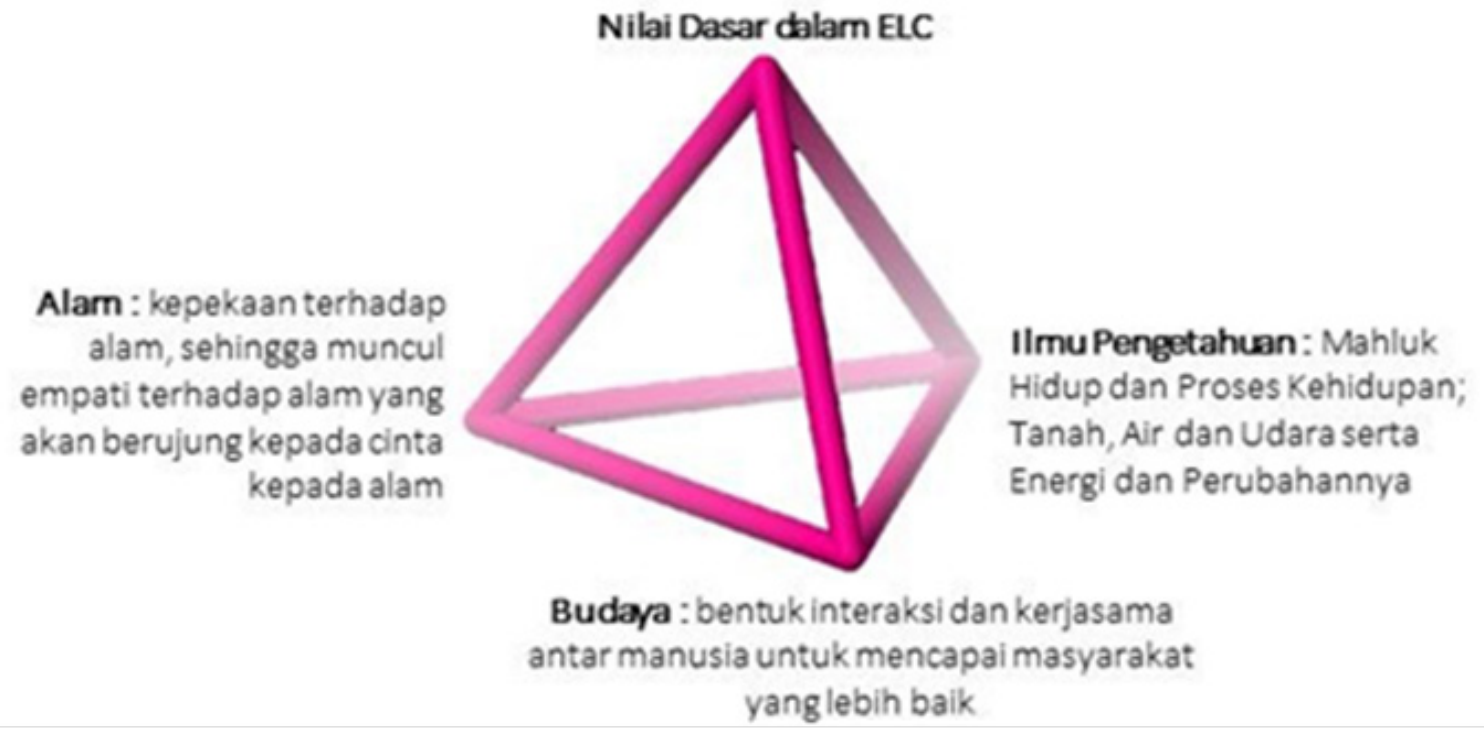

GAMBAR 1. Pilar Program Edukasi Eco Learning Camp

Sumber: www.ecolearningcamp.org

dengan Balai Pengelolaaan Taman Hutan Raya Djuanda Dinas Kehutanan Pemda Jawa Barat dan Universitas Katolik Parahyangan.

\section{Pendidikan Nilai di Eco Camp}

Dalam perspektif Parsons, pendidikan merupakan proses sosialisasi dalam diri individu yang memungkinkan berkembangnya rasa tanggung jawab dan kecakapan-kecakapan (commitment dan capacities) yang diperlukan dalam melaksanakan peran social (Maunah, 2016).

Pendidikan di Eco Camp merupakan pendidikan nonformal mengenai nilai yang disampaikan melalui wacana lingkungan hidup yang diintegrasikan dengan pengetahuan mengenai sains dan budaya yang terkait untuk memunculkan kesadaran akan pentingnya lingkungan hidup sehingga terwujud partisipasi aktif untuk menjaga lingkungan hidup. Program pendidikan di Eco Camp berlandaskan pada alam, budaya dan ilmu pengetahuan.

Adapun nilai dasar yang ditanamkan dalam pendidikan lingkungan di Eco Learning Camp terdiri dari integritas, semangat berbagi, tanggung jawab dan penghargaan.

\section{Kearifan Lokal dalam Pendidikan Nilai di Eco Learning Camp}

Bentuk-bentuk kearifan lokal yang ada di masyarakat menurut Aulia dan Dharmawan (2010) dapat berupa nilai, norma, kepercayaan dan aturanaturan khusus. Fungsi kearifan lokal tersebut antara lain untuk: (1) konservasi dan pelestarian sumber daya alam; (2) mengembangkan sumberdaya manusia; (3) pengembangan kebudayaan dan ilmu pengetahuan; serta (4) petunjuk tentang petuah, kepercayaan, sastra, dan pantangan.

Berkaitan dengan perlindungan dan pengelolaan lingkungan hidup, UU No. 32 Tahun 2009 tentang Perlindungan dan Pengelolaan Lingkungan Hidup mendefinisikan kearifan lokal sebagai nilai-nilai luhur yang berlaku dalam tata kehidupan masyarakat untuk antara lain melindungi dan mengelola lingkungan hidup secara lestari. Pada pasal 2 disebutkan bahwa perlindungan dan pengelolaan lingkungan hidup dilaksanakan berdasarkan beberapa asas 

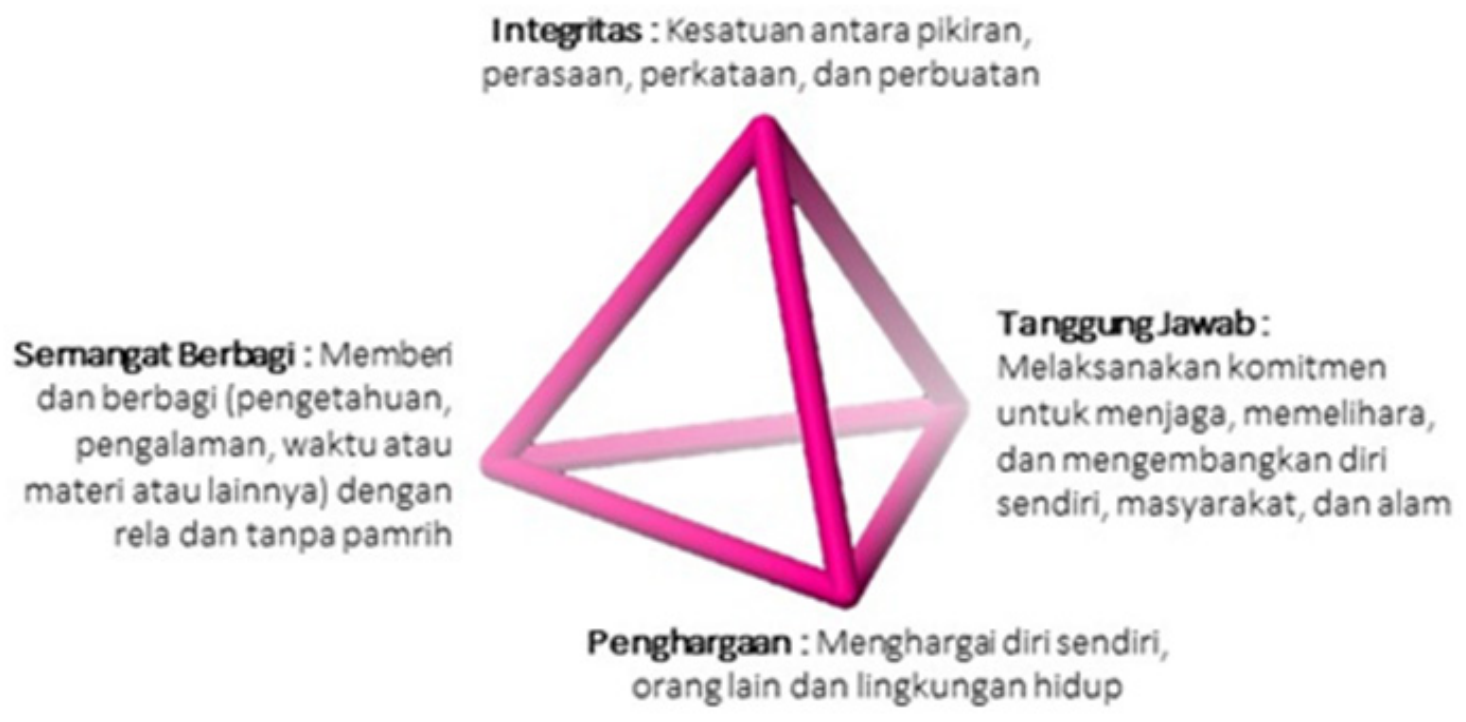

GAMBAR 2. Nilai Dasar dalam Edukasi Eco Learning Camp

Sumber: www.ecolearningcamp.org

yang salah satunya adalah asas kearifan lokal. Kemudian pada penjelasan Pasal 2 huruf (1) disebutkan yang dimaksud dengan "asas kearifan lokal" adalah bahwa dalam perlindungan dan pengelolaan lingkungan hidup harus memperhatikan nilai-nilai luhur yang berlaku dalam tata kehidupan masyarakat.

Lebih lanjut dalam undangundang tersebut, pada Pasal 70 ayat (1) disebutkan bahwa masyarakat memiliki hak dan kesempatan yang sama dan seluas-luasnya untuk berperan aktif dalam perlindungan dan pengelolaan hidup yang pada ayat (3e) disebutkan salah satu peran masyarakat adalah mengembangkan dan menjaga budaya dan kearifan lokal dalam rangka pelestarian fungsi lingkungan hidup.

Dalam hubungannya dengan kehidupan manusia sebagai bagian dari sistem ekologis, Keraf (dalam Iskandar, 2014) menyatakan istilah kearifan ekologi merupakan pengetahuan, keyakinan, pemahaman atau wawasan, serta adat kebiasaan yang menuntun perilaku manusia dalam kehidupan di dalam komunitas ekologis. Pada umumnya, kearifan ekologi tersebut dimiliki dan disebarluaskan secara kolektif kepada semua anggota komunitas. Berbagai pengetahuan tersebut menyangkut banyak aspek misalnya tentang jenis tanaman, binatang, batuan dan mineral, topografi, tata guna lahan, jenis-jenis dan kesuburan tanah, tipe vegetasi, penggunaan tumbuhan dan binatang untuk bahan obat-obatan, penyakit manusia dan hewan, gejala meteorologis, dan lain sebagainya.

Kearifan ekologi inilah yang diterapkan di Eco Camp oleh para pengelolanya. Berawal dari kepedulian akan kondisi lingkungan hidup yang semakin memprihatinkan akibat pola hidup manusia, Eco Camp didirikan untuk berbagi pengetahuan dan pengalaman mengenai betapa pentingnya menjaga kelestarian lingkungan alam dan sekitarnya untuk kelangsungan hidup manusia di masa mendatang. Jalur pendidikan lah yang kemudian dipilih untuk membuka wawasan dan kesadaran masyarakat akan pentingnya menjaga kelestarian lingkungan alam.

Dalam lingkungan Eco Camp, sebagai suatu lembaga yang berorientasi pada pendidikan nilai dan pendidikan 
ekologis, bentuk-bentuk kearifan lokal yang diterapkan antara lain dalam pemanfaatan lahan, pemanfaatan hasil lahan, permainan tradisional, pengolahan dan pemanfaatan makanan, pemanfaatan hasil limbah, penanaman nilai-nilai ekologis.

\section{Pemanfaatan Lahan}

Eco Learning Camp memiliki area kebun seluas 2.000 meter persegi. Setengah dari luas lahan tersebut atau 1.000 meter persegi digunakan untuk area sayuran. Pemupukan menggunakan pupuk organik dan pestisida organik. Sayuran yang ditanam di area kebun digunakan untuk konsumsi sendiri sehingga sayuran yang dihasilkan lebih sehat dan bermanfaat bagi kesehatan individu yang mengonsumsinya. Menurut Ferry Sutrisna Wijaya, salah seorang pendiri Eco Camp, salah satu tugas Eco Camp sebagai rumah belajar lingkungan hidup adalah menawarkan terus menerus hidup yang lebih organik. Pemanfaatan lahan dan penggunakan pupuk organik merupakan bagian dari upaya untuk menghargai lingkungan dengan melestarikan kesuburan tanah sebagai salah satu bagian dari kearifan lokal Sunda yang menjaga hubungan harmonis dengan alam.

\section{Pengolahan dan Pemanfaatan Makanan}

Makanan yang dikonsumsi di Eco Camp merupakan hasil olahan sendiri yang dimasak dari tanaman hasil kebun milik sendiri. Peserta maupun pengelola Eco Camp diajari untuk hidup vegetarian dengan tidak menyediakan makanan yang bersumber dari daging. Ketentuan tidak disediakannya makanan berbahan dasar daging, menurut Ferry berdasarkan kenyataan bahwa industri ini menjadi penyumbang bagi pemanasan global. Dengan demikian, hidup vegetarian merupakan salah satu solusi untuk menghormati hewan dan menghargai keberadaan mereka yang dalam industri daging, diperlakukan semena-mena. Mengonsumsi sayur dan buah-buahan merupakan satu upaya menerapkan kearifan lokal menghargai sesama makhluk hidup. Kemudian dalam mengonsumsi makanan, diupayakan untuk makan secukupnya, agar tidak ada sisa.

\section{Pemanfaatan Hasil Limbah}

Limbah yang dihasilkan dari makanan yang dikonsumsi di Eco Camp diolah secara terpisah dengan memisahkan terlebih dulu limbah organik dan nonorganic pada saat selesai mengonsumsi makanan. Limbah organik diolah menjadi kompos agar bisa dimanfaatkan sebagai pupuk bagi tanaman di area kebun milik Eco Camp.

\section{Permainan Tradisional}

Permainan tradisional merupakan salah satu cara yang digunakan di Eco Camp untuk menanamkan nilai-nilai moral yang terkait dengan lingkungan hidup. Menurut Ferry, dalam permainan tradisional terdapat banyak nilai yang bisa ditanamkan kepada peserta permainan. Nilai-nilai tersebut di antaranya kejujuran, keberanian, kebesaran hati untuk menerima kekalahan, kerja sama, sportifitas, saling menghormati, kesederhanaan dan sebagainya. Ide untuk menyertakan permainan tradisional dalam penanaman nilai-nilai moral kebaikan dan nilai lingkungan hidup, karena permainan tersebut sumbernya dari alam sehingga bisa dikembalikan lagi ke alam untuk menanamkan nilainilai kebaikan. Ferry merasa, nilai-nilai dalam permainan tersebut masih tetap relevan untuk diterapkan dalam kondisi masa kini. Dengan permainan tradisional, penanaman nilai-nilai moral tidak terasa dipaksakan, karena prosesnya tidak langsung disampaikan, melainkan melalui pemaknaan terhadap nilai- 
nilai moral permainan berupa refleksi yang disampaikan setelah permainan dilaksanakan.

Ferry meyakini apabila anak-anak sering bermain tradisional kemudian bisa menghayati nilai-nilai di dalamnya dan melaksanakan nilai-nilai itu dalam kehidupan sehari, akan terwujud masyarakat yang lebih baik, yang lebih damai, tidak merusak, berdamai dengan sesama manusia, berdamai dengan alam semesta sehingga hidup lebih nyaman.

\section{Penanaman Nilai-nilai Ekologis melalui Komunikasi Lingkungan}

Metode pendidikan nilai di Eco Camp dilakukan melalui ceramah, penayangan film dan pemberian contoh. Tujuannya untuk membuka kesadaran. Namun, metode pendidikan nilai yang paling utama adalah pembiasaan. Apa yang telah disampaikan melalui ceramah, penayangan film dan pemberian contoh, kemudian dibiasakan dalam kehidupan sehari-hari, agar orang sadar dan belajar melayani diri sendiri. Metode pembiasaan diterapkan di lingkungan pegawai dan tamu Eco Camp. "Jadi bukan memberitahu, bukan ngajarin tapi membiasakan atau ditubuhkan, harus sampai dilaksanakan secara fisik," ujar Ferry.

Selain itu, di Eco Camp diajarkan pula nilai-nilai kebersamaan yang menghargai perbedaan di lingkungan yang multikultur, interfaith, mindfullness, dan ekologi. Melalui penerapan nilai-nilai kebersamaan, agama dan suku bukan lagi pembatas, melainkan menjadi lebih cair. Intinya adalah membuka pikiran, hati, tenang dan lebih banyak mendengarkan.

Penanaman nilai-nilai ekologis di Eco Learning Camp dilakukan melalui 7 kesadaran baru hidup ekologis, yang terdiri dari pola hidup berkualitas, sederhana, hemat, peduli, semangat berbagi, bermakna dan harapan. (1) Berkualitas: mampu mengolah kelemahan dan belajar

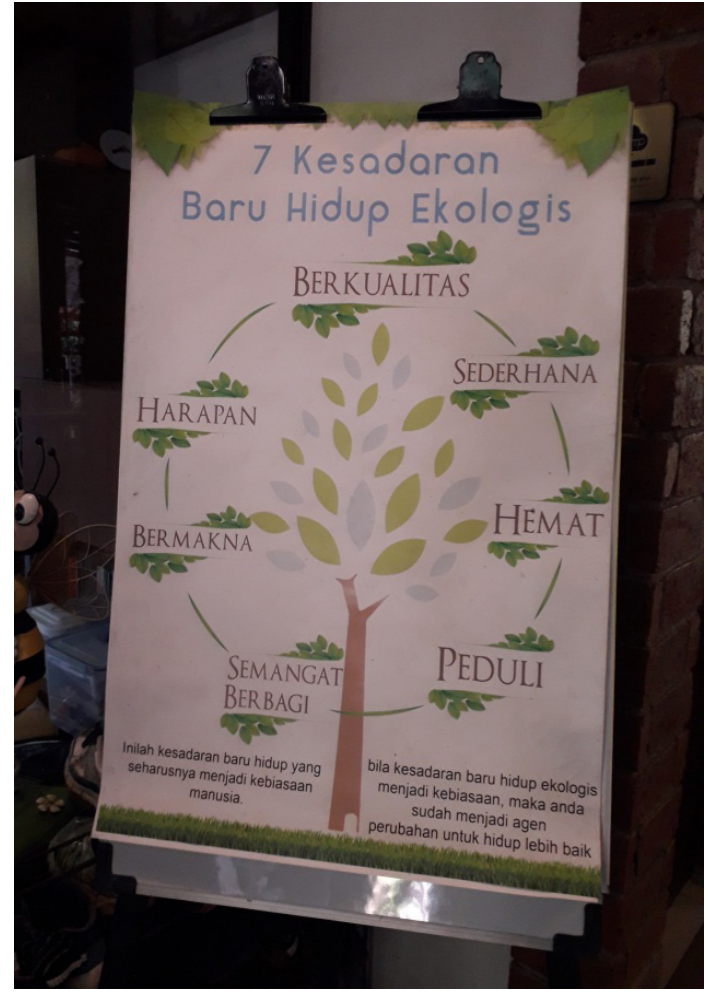

GAMBAR 3. Tujuh Kesadaran Baru Hidup Ekologis yang disosialisasikan di Eco Camp (Sumber: ecolearningcamp.org)

bertanggung jawab dengan melakukan pekerjaan sendiri. (2) Sederhana dalam pola pikir dan pola hidup. Misalnya tidak berlebihan dalam makan, belanja dan kepemilikan. (3) Hemat: memanfaatkan sumber daya secukupnya dan tidak berlebihan. (4) Peduli kepada diri sendiri dan lingkungan sekitar, yang digerakkan oleh ketulusan hati. (5) Berbagi dalam keterbatasan, baik materi, ilmu dan sebagainya. (6) Bermakna: menemukan makna hidup dan kebahagiaan dengan cara sederhana. Misalnya berbagi dengan orang lain. (7) Harapan: menjadi pribadi pembawa harapan dengan melakukan kebaikan di lingkungan masing-masing.

Penerapan ketujuh kesadaran baru hidup ekologis tersebut dilaksanakan melalui gaya hidup ekologis dan sederhana, yakni: BBM (Bawa Botol Minum) untuk membiasakan minum air putih dan mengurangi cucian gelas; Minim plastik dan kemasan untuk mengurangi sampah yang menghasilkan 


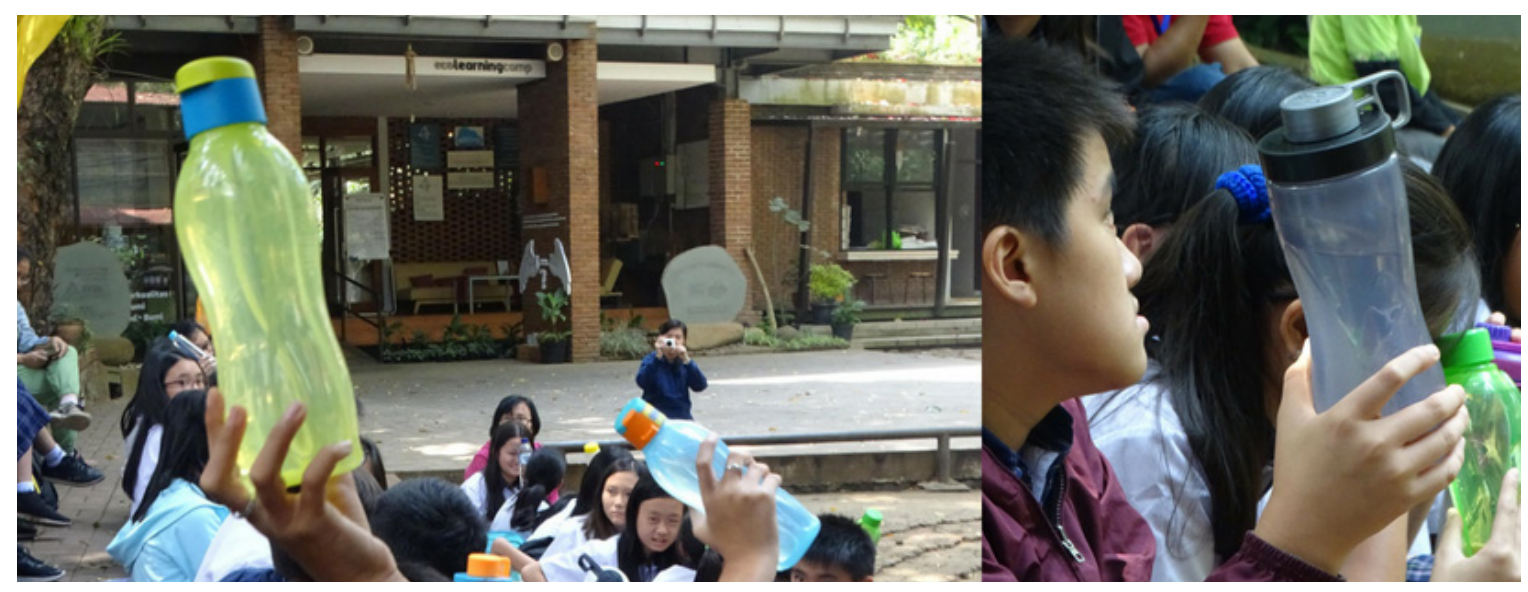

GAMBAR 4. Salah satu realisasi dari kesadaran baru hidup ekologis, yakni membawa botol minum sendiri. (Sumber: ecolearningcamp.org)

racun; Bebas asap rokok. Jika ada yang merokok, dikenai kompensasi pembersihan udara sebesar Rp 500.000; Lifeskill, belajar keterampilan sederhana pendukung kehidupan sehari-hari, seperti merapikan kamar, mencuci piring, memasang sprei, membantu masak, dan lainnya; Pola hidup sederhana; mengambil makanan dengan memperhatikan temanteman yang lain, tidak ada makanan sisa, makanan sederhana dan sehat, minum air putih sehat; Pola hidup hemat; menggunakan energi listrik secara bijaksana dan hemat, menggunakan air secukupnya.; Waktu hening sesaat di jam 12.00 dan jam 15.00, dimana semua aktivitas harus dihentikan dan belajar mendengarkan suara alam. Waktu hening merupakan bagian dari pendidikan nilai untuk menggugah kesadaran bahwa kita hidup terlalu cepat, harus melambat. Juga sebagai ungkapan rasa syukur masih diberi kesempatan hidup. Dengan munculnya kesadaran tersebut, perilaku lebih tertata dan bertanggung jawab.

\section{Makna Pendidikan Nilai dan Lingkungan Hidup}

Individu dalam dunia makna. Setiap individu hidup akan memberikan makna terhadap segala hal yang ditemui di sekitarnya, baik yang terlihat secara fisik maupun yang bersifat nonfisik, yang hanya bisa dirasakan seperti gagasan atau perasaan di antara individu. Umumnya, manusia akan bertindak terhadap sesuatu (benda, peristiwa dan lainlain) berdasarkan makna yang dimiliki sesuatu tersebut bagi mereka. Makna terbentuk melalui proses berpikir individu terhadap aspek yang ingin diberi makna berlandaskan muatan informasi yang dimilikinya. Proses berpikir individu dipengaruhi faktor-faktor dalam dirinya, seperti sistem nilai, kepercayaan dan sikap sehingga makna yang dihasilkan individu terhadap suatu objek yang sama akan berbeda (Bajari, 2009: 30).

Makna mendasari tindakan seseorang. Blumer dalam Griffin (2006: 56-59) mengemukakan tiga premis yang mendasari tindakan seseorang, yaitu (1) humans act toward people or things on the basis of meanings they assign to those people or things. (2) the meaning arises out of the social interaction that people have with each other. (3) an individual's interpretation of symbols is modified by his or her own thought process. Manusia bertindak pada seseorang atau sesuatu berdasarkan makna yang dimilikinya tentang orang atau sesuatu tersebut; makna timbul dari interaksi sosial yang dilakukan seseorang dengan 
orang lain; Interpretasi seseorang pada simbol/lambang dipengaruhi oleh proses berpikirnya.

Berdasarkan penjelasan tersebut, maka, pendidikan nilai dan lingkungan hidup merupakan ekspresi dari pemaknaan subjek penelitian terhadap kearifan lokal yang berkaitan dengan pemeliharan lingkungan hidup. Bagi Ferry Sutrisna Wijaya, sebagai informan utama penelitian ini, pendidikan nilai dan lingkungan hidup melalui Eco Learning Camp merupakan cara yang dikuasai dan disukainya untuk menyampaikan manifestasi dari pola pikir atau pemaknaan yang dimilikinya tentang menyelamatkan bumi berlandaskan kearifan lokal masyarakat Indonesia. Unsur keberakaran pada budaya menjadi landasan utama bagi Ferry dalam melakukan aktivitasnya.

\section{Bentuk-bentuk Komunikasi Lingkungan di Eco Camp}

Seperti yang disampaikan oleh Angga Ariestya bahwa ada dua fungsi komunikasi lingkungan, yaitu fungsi strategis dan fungsi teknis. Dari dua fungsi komunikasi lingkungan tersebut, fungsi strategislah yang lebih dominan dilakukan oleh Eco Camp dalam menumbuhkan kesadaran masyarakat untuk peduli pada lingkungan alam melalui beragam kegiatan yang dirancangnya. Fungsi teknik pun dilakukan Eco Camp dengan menyampaikan informasi mengenai permasalahan-permasalahan terkait ekologi melalui website maupun media sosial. Fungsi ini selaras dengan pernyataan Herlina Agustin, pemerhati lingkungan dari Profauna yang mengatakan bahwa komunikasi lingkungan adalah upaya menyadarkan khalayak untuk menjaga lingkungan melalui berbagai saluran komunikasi. Peran komunikasi lingkungan adalah mengomunikasikan berbagai bentuk kerusakan lingkungan dan upaya penyelamatannya (Agustin, 2016).

\section{Komunikasi Kelompok}

Di Eco Camp, materi pendidikan lingkungan disampaikan secara berkelompok, baik kelompok besar maupun kelompok kecil. Pemberian materi secara berkelompok ini dilakukan rangka efisiensi dan efektifitas penyampaian. Komunikasi kelompok biasanya dilakukan pada saat brainstorming dan diskusi mengenai materi yang terkait dengan pendidikan nilai maupun lingkungan hidup. Dalam praktiknya, pendidikan nilai yang sifatnya kebersamaan dan menjalin kekompakan sesama peserta dilakukan secara berkelompok. Antara lain dalam permainan tradisional, permainan yang melatih kekompakan sesama peserta, berkebun, dan lainnya.

\section{Komunikasi Instruksional}

Komunikasi instruksional merupakan bagian dari komunikasi edukatif, yaitu komunikasi yang dirancang khusus untuk mengubah perilaku pihak sasaran. Dalam dunia pendidikan, kata instruksional tidak diartikan perintah, melainkan pengajaran atau pembelajaran. Komunikasi instruksional pada dasarnya mempunyai tujuan untuk memahamkan pihak sasaran (komunikan) dalam hal adanya perubahan perilaku ke arah yang lebih baik di masa yang akan datang. Perubahan perilaku yang dimaksud terutama pada aspek kognitif, afeksi, dan psikomotor.

Pesan adalah informasi yang ditransmisikan atau diteruskan oleh komponen lain dalam bentuk ide, ajaran, fakta, nilai, makna maupun data. Informasi yang terkandung dalam setiap pelajaran adalah pesan. Dalam hal ini pesan belajar, pesan yang dirancang khusus untuk tujuan belajar dan untuk mempermudah terjadinya proses belajar (Yusup, 1990: 20)

Demikian pula dengan pendidikan 


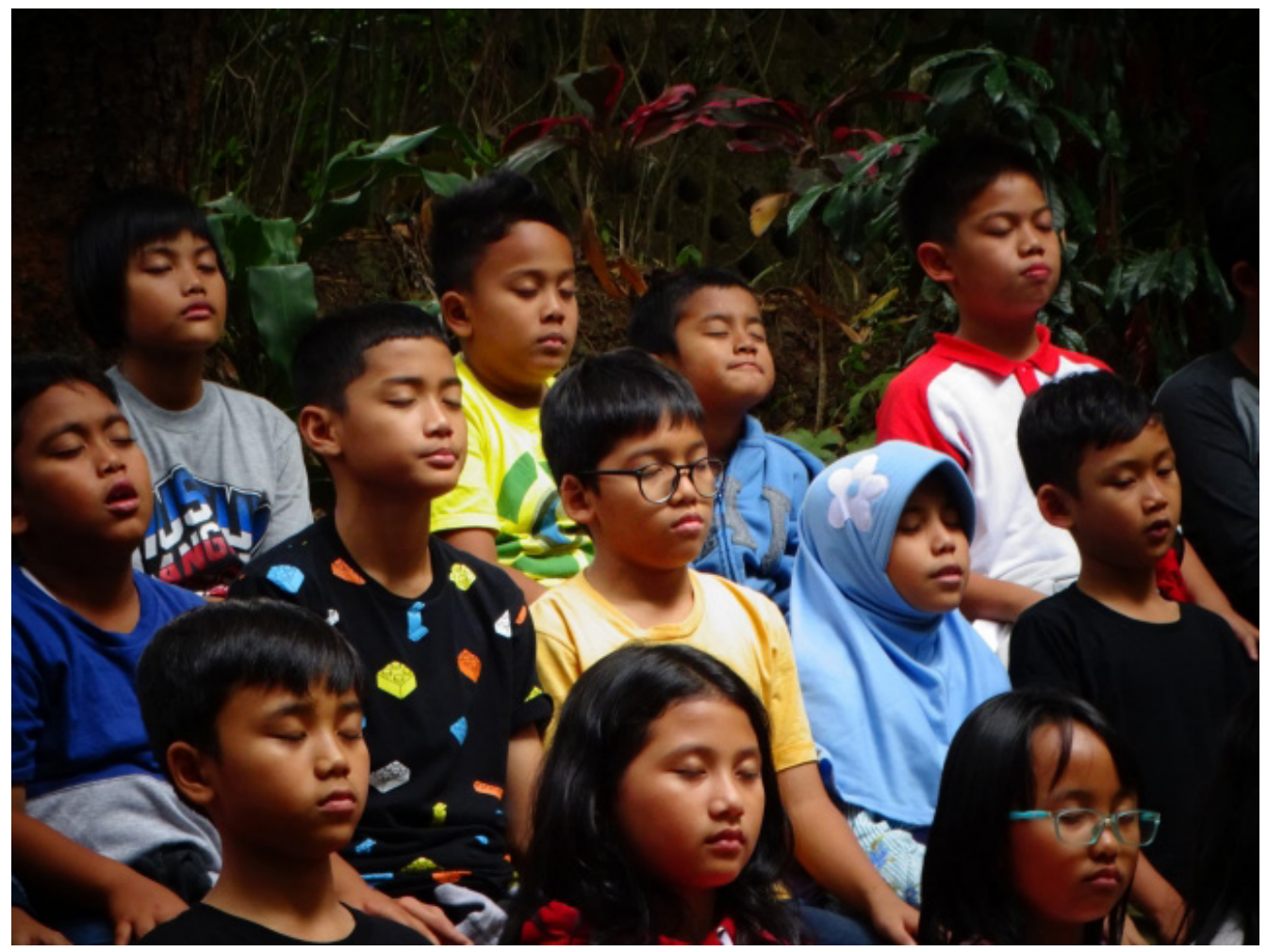

GAMBAR 5. Kegiatan meditasi sebagai salah satu cara untuk menenangkan diri dan menyatu dengan alam di Eco Camp (Sumber: ecolearningcamp.org)

nilai di Eco Camp. Komunikasi instruksional digunakan sebagai salah satu metode penyampaian pesan yang bersifat mengarahkan. Melalui bentuk komunikasi ini, peserta pelatihan diajak untuk aktif berpatisipasi dalam kegiatan yang diselenggarakan di sana dengan mengikuti instruksi dari pemandu kegiatan.

Komunikasi instruksional yang terjadi di Eco Camp berlangsung pada saat waktu hening pada saat jam 12.00 dan jam 15.00. Pada saat waktu hening tiba, yang ditandai dengan bunyi isyarat melalui pengeras suara, terdengar suara laki-laki yang menginformasikan waktu hening telah tiba dan menginstruksikan semua orang yang ada di Eco Camp untuk menghentikan sejenak kegiatannya untuk menenangkan diri dan menikmati suara alam dari lingkungan di Eco Camp. "Kita memasuki waktu hening. Silakan dengar suaara alam sekitar. Renungkan, tarik nafas dalam-dalam dan lepaskan perlahan". Demikian suara yang terdengar dari pengeras suara. Selanjutnya, suara perempuan terdengar untuk menginstruksikan urutan waktu hening yang dilakukan oleh semua orang yang ada di Eco Camp. Setelah waktu hening selesai selama kurang lebih dua menit, semua orang di Eco Camp diinformasikan dapat melakukan aktivitasnya kembali.

Komunikasi instruksional juga dilakukan saat berlangsung kegiatan di luar ruangan, seperti berkebun, melakukam permainan motivasi maupun permainan tradisional. Fungsi dari komunikasi instruksional adalah sebagai pemandu kegiatan yang berlangsung di Eco Camp.

\section{Komunikasi Bermedia}

Pendidikan nilai berupa penanaman kebiasaan untuk melakukan 7 kesadaran baru hidup ekologis di Eco Camp, 
dilakukan tidak hanya melalui komunikasi tatap muka, juga melalui komunikasi bermedia. Penyampaian informasi kepada khalayak sasaran dilakukan menggunakan media komunikasi, yakni perantara dalam penyampaian informasi dari komunikator kepada komunikan yang bertujuan untuk efisiensi penyebaran informasi atau pesan.

Komunikasi media adalah
komunikasi yang dilakukan
menggunakan media, namun bukan berupa media massa tetapi media lain berupa telepon, faks, surat, email, chat, dll. Komunikasi ini berada di tengahtengah antara komunikasi antar personal dan komunikasi massa. Hal ini lebih berkembang ketika munculnya media baru yaitu internet. Penemuan internet dan perkembangannya sangat cepat sehingga internet sangat mudah merubah tatanan komunikasi antarmanusia. Yang pada awalnya masyarakat lebih menekankan komunikasi tatap muka, namun berubah menjadi menggunakan media, yang lebih sering digunakan adalah telepon selular

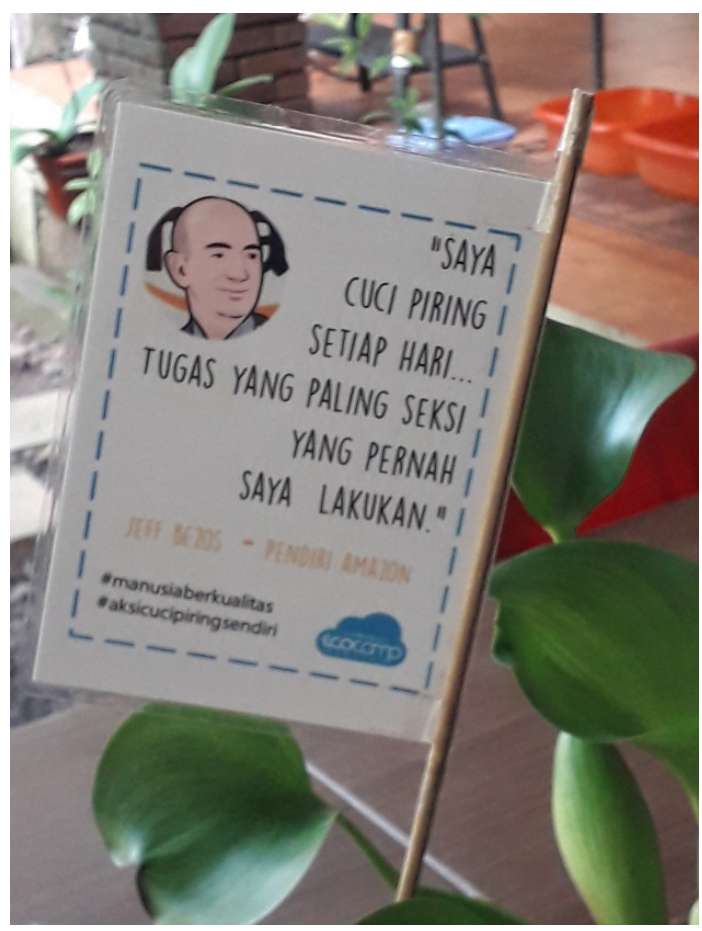

dan internet.

Media komunikasi merupakan perantara dalam penyampaian informasi dari komunikator kepada komunikate yang bertujuan untuk efisiensi penyebaran informasi atau pesan tersebut. Onong Uchyana Effendy membagi dua komunikasi bermedia menjadi dua, yakni komunikasi bermedia massa dan komunikasi bermedia nirmassa. Komunikas bermedia massa digunakan dalam komunikasi dengan jumlah peserta banyak dan bertempat tinggal jauh. Media massa yang digunakan adalah radio, sura kabar, televisi yang beroperasi dalam bidang informasi, edukasi dan rekreasi. Sementara komunikasi bermedia nirmassa digunakan dalam komunikasi untuk orang-orang tertentu atau kelompokkelompok tertentu. Media nirmassa tidak memiliki daya keserempakan dan komunikasinya tidak bersifat massal. Media yang digunakan antara lain papan pengumuman, poster, spanduk, pamphlet, brosur, surat, telegram, telex, dll. (Effendy, $1986: 11$ ).

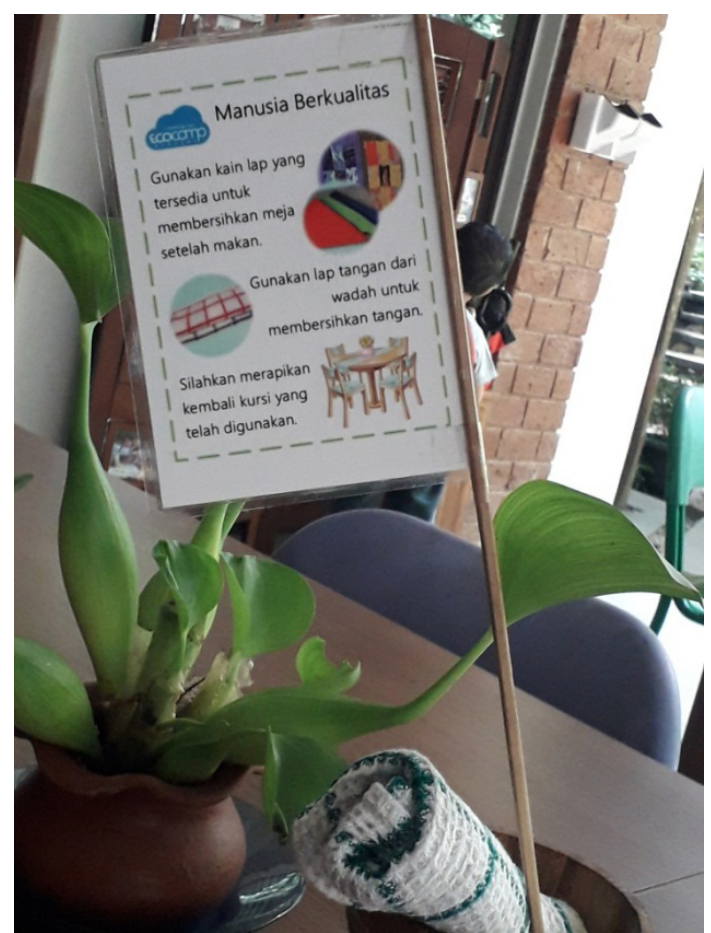

GAMBAR 6. Bentuk komunikasi menggunakan media untuk hidup ekologis di Eco Camp (sumber: dokumentasi penulis) 
Dalam lingkungan Eco Camp, komunikasi bermedia nirmassa lebih banyak digunakan dalam menyampaikan informasi maupun mempersuasi peserta pelatihan dan pengelola Eco Camp untuk melakukan aktivitas sesuai dengan yang tertera dalam media nirmassa yang digunakan. Adapun media yang digunakan berupa stiker, poster, gambar dan lainnya. Dengan menggunakan media nirmassa, diharapkan pesan yang disampaikan dapat diketahui dengan cepat dan menghemat waktu karena tidak perlu melakukannya berulang-ulang untuk mengingatkan atau mengajak semua orang di Eco Camp untuk melakukan kebiasaan yang menunjang pola hidup ekologis.

\section{SIMPULAN}

Alam dan manusia sejatinya berada dalam posisi yang sejajar sebagai sesama ciptaan Tuhan. Keharmonisan hubungan keduanya merupakan pola hidup yang seharusnya dijalankan oleh masyarakat maupun manusia. Dalam pemanfaatan alam, manusia tidak boleh mengeksploitasi, namun memanfaatkan alam sesuai kebutuhannya. Alam tidak sekadar dipandang dari sisi "ekonomis" untuk memenuhi kebutuhan hidup dan kehidupannya, melainkan sebagai mitra yang harus dijaga keberadaannya dengan menciptakan hubungan yang selaras di antara keduanya.

Eco Learning Camp didirikan untuk membangun kesadaran dan kepedulian pada lingkungan hidup yang diharapkan muaranya pada munculnya keinginan untuk melakukan tindakan nyata dalam menjaga lingkungan hidup. Komunikasi lingkungan yang disampaikan secara menyenangkan dalam pendidikan nilai berbasis lingkungan hidup di Eco Camp diharapkan dapat berkontribusi pada munculnya kesadaran untuk menjaga hubungan yang baik dengan lingkungan alam sekitar. Masa anak-anak dan remaja merupakan masa yang tepat untuk menerima pemahaman tentang kesadaran akan pentingnya mencintai lingkungan dan menjaga kelestariannya agar alam memberikan timbal balik yang positif kepada manusia.

\section{DAFTAR PUSTAKA}

Agustin, Herlina. (2016) Komunikasi Lingkungan Berperan Menyadarkan Khalayak Menjaga Lingkungan. unpad.ac.id. 23/12/2016. http://www.unpad. ac.id/profil/dr-herlina-agustin-ssos-m-t-komunikasi-lingkunganberperan-menyadarkan-khalayakmenjaga-lingkungan/

Ariestya,Angga.(2017).Mempertanyakan Eksistensi Komunikasi Lingkungan. https://nasional.kompas.com/ $\mathrm{read} / 2017 / 09 / 18 / 08220681 /$ mempertanyakan-eksistensikomunikasi-lingkungan-di indonesia. Diakses 10 November 2018.

Aulia, T.O.S., Dharmawan, A.H. (2010). Kearifan Lokal dalam Pengelolaan Sumberdaya Air di Kampung Kuta. Sodality: Jurnal Transdisiplin Sosiologi, Komunikasi dan Ekologi Manusia. 4(3): 345-355.

Bajari, Atwar. (2009). Konstruksi Makna dan Perilaku Komunikasi pada Anak Jalanan di Cirebon. Disertasi. Bandung: Universitas Padjadjaran.

Budiwiyanto. (2006). Tinjauan Tentang Perkembangan Pengaruh Local Genius dalam Seni Bangunan Sakral (Keagamaan) di Indonesia. Ornamen 2(1): 25-35.

Fajarini, U. (2014). Peranan Kearifan Lokal dalam Pendidikan Karakter. Sosio Didaktika 1(2): 123-130.

Griffin, E. (2006). A First Look at Communication Theory. New York: McGraw- Hill. Inc

Indrawardana, I. (2012). Kearifan Lokal 
Adat Masyarakat Sunda dalam Hubungan dengan Lingkungan Alam. Komunitas 4(1): 1-8. http:// journal.unnes.ac.id/nju/index.php/ komunitas., Diakses 10 November 2018

Iskandar, J. (2014). Manusia dan Lingkungan dengan Berbagai Perubahannya. Yogyakarta: Graha Ilmu.

Maridi. (2015). Mengangkat Budaya dan Kearifan Lokal dalam Sistem Konservasi Tanah dan Air. Prosiding Seminar Nasional Biologi (1) 20-39. http://jurnal.fkip. uns.ac.id/index.php/prosbio/article/ view/7052, Diakses 10 November 2018

Maunah, Binti. (2016). Pendidikan dalam Perspektif Struktural Fungsional. Cendekia 10(02): 159-178.

Negara, P.D. (2011). Rekonstruksi Kebijakan Pengelolaan Kawasan Konservasi Berbasis Kearifan Lokal sebagai Kontribusi Menuju Pengelolaan Sumber Daya Alam yang Indonesia. Jurnal Konstitusi IV(2): 91-138.
Rahmat, Agus. (2018). Menggagas Kajian Baru dalam Ilmu Komunikasi, dalam Yenrizal, 2018. Etnoekologi Komunikasi: Orang Semende Memaknai Alam. Yogyakarta: Phoenix Publisher

Suhartini. (2009). Kajian Kearifan Lokal Masyarakat dalam Pengelolaan Sumberdaya Alam dan Lingkungan. Prosiding Seminar Nasional Penelitian, Pendidikan, dan Penerapan MIPA. Fakultas MIPA Universitas Negeri Yogyakarta yang diselenggarakan pada 16 Mei 2009.

Undang-Undang Nomor 32 Tahun 2009 tentang Perlindungan dan Pengelolaan Lingkungan Hidup Eco Camp dan Tujuh Kesadaran Baru Hidup Ekologis. http:// jpicofmindonesia.com/2016/09/ eco-camp-dan-tujuh-kesadaranbaru-hidup-ekologis https://www. ecolearningcamp.org/ Diakses 10 November 2018 